\title{
The rationale behind collecting umbilical cord blood
}

\author{
Umbilikal kordon kanı toplanmasının altında yatan gerçek
}

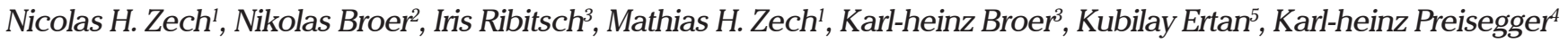 \\ ${ }^{1}$ Iuf Centers Prof. Zech, Bregenz, Austria and Department For Obstetrics and Gynecology, Unit of Gynecological \\ Endocrinology and Reproductive Medicine, University of Graz, Austria \\ ${ }^{2}$ Yale University School of Medicine, Usa, and Center For Reproductive Medicine, Cologne, Germany \\ ${ }^{3}$ Vivocell Biosolutions Gmbh, Graz, Austria and Langenfeld/ Düsseldorf, Germany \\ ${ }^{4}$ Translational Center For Regenerative Medicine, University of Leipzig, Germany \\ ${ }^{5}$ Klinikum Leverkusen, Department of Obstretics and Gynecology, Leverkusen, Germany
}

\section{Abstract}

Umbilical cord blood (UCB) is an increasingly important and rich source of stem cells. These cells can be used for the treatment of many diseases, including cancers and immune and genetic disorders. For patients for whom no suitable related donor is available, this source of hematopoietic stem cells offers substantial advantages, notably the relative ease of procurement, the absence of risk to the donor, the small likelihood of transmitting clinically important infections, the low risk of severe graft-versus-host disease (GVHD) and the rapid availability of placental blood for transplantation centers. Even though almost 80 diseases are treatable with cord blood stem cells, 97 percent of cord blood is still disposed of after birth and lost for patients in need! To improve availability of stem cells to a broader community, efforts should be undertaken to collect cord blood and expectant parents should be properly informed of their options with regard to cord blood banking.

(J Turkish-German Gynecol Assoc 2010; 11: 99-101)

Key words: Stem cell, umbilical cord blood, collection, allogeneic, autologous, transplantation

Received: 26 November, 2009

Accepted: 31 December, 2009

\section{Özet}

Umbilikal kordon kanı kök hücre zengin bir kök hücre kaynağıdır ve önemi gittikçe artmaktadır. Bu hücreler kanser, immun ve genetik birçok hastalığın tedavisinde kullanılmaktadırlar. Uygun donor bulunamayan hastalar için bu hemopoetik kök hücre kaynağı birçok avantajlar sunar. Bunlar; işleme için kolaylık, donor bulunmama riskinin ortadan kalkması, klinik önemi olan enfeksiyon hastalıklarının bulaşma oranının düşük olması, greft reddi oranının az olması ve plasenta kanının tarnsplantasyon merkezlerine kolayca ulaştırılması gibi. Kordon kanındaki kök hücreler ile şu an yaklaşık olarak 80 kadar hastalık tedavi edilebilirken, ne yazık ki kordon kanlarının \%97'si hala atılmakta ve hastalar tedavi şanslarını yitirmektedirler. Kök hücrelerin bulunabilirliğini arttırmak ve tüm topluma ulaştırmak için, kordon kanını toplamak ve çiftleri kordon kanı bankacılığı hakkında yeterli bilgilendirmek için çaba harcanmalıdır.

(J Turkish-German Gynecol Assoc 2010; 11: 99-101)

Anahtar kelimeler: Kök hücre, umbilikal kord kanı, toplama, allojenik, otolog, transplantasyon

Geliş Tarihi: 26 Kasım 2009

Kabul Tarihi: 31 Aralık 2009

\section{Introduction}

Bone marrow (BM) and peripheral blood (PB) stem cell (SC) transplantations from human leukocyte antigen (HLA)-identical sibling donors have been used for many years in the treatment of hematological malignancies, BM failure syndromes, selected hereditary immunodeficiencies and metabolic disorders. A higher probability of successful engraftment and a reduction in the risk of potentially fatal graft-versus-host disease (GVHD) is conferred with close matching. Unfortunately, there is only a $25-30 \%$ chance of identifying a full sibling donor HLA match $(1,2)$. An alternative to a related donor involves seeking unrelated HLA-matched adult allogeneic donors outside the family. Today more than 13 million potential unrelated volunteer adult donors are registered in the Bone Marrow Donor Worldwide registry (3). However, more than
$50 \%$ of all patients are unable to find a suitable adult donor in a timely manner (4) and only $30-40 \%$ of donor searches result in unrelated donor SC transplantation (5). Non-caucasians have an overall lower chance of identifying a fully matched unrelated adult donor because of genetic heterogeneity and under-representation of non-white donors in the registries (6).

Umbilical cord blood transplantation for children and adults Umbilical cord blood (UCB) has been evaluated by clinical investigators as an alternate source for SC transplantation in an attempt to increase the availability of suitable donors and reduce the morbidity and mortality associated with allogeneic BM- and PB-SC transplantation (7-11). Many patients who are unable to identify a BM- or PB-SC donor can now benefit from a partially or fully matched UCB due to advances in the clinical practice of cord blood transplantation. Initially, UCB-SC 
transplantation using allogeneic UCB was performed in small children. However, in the meantime it has been proven that older children, adolescents, and adults can also be successfully transplanted with unrelated allogeneic UCB (12) In fact, almost $50 \%$ of the transplanted allogeneic UCB units facilitated by the National Marrow Donor Program in 2008 were for adults (13). Furthermore, recently, the first child with leukaemia was successfully treated with her own UCB (14).

\section{Umbilical cord blood for regenerative medicine}

Additionally, SC from UCB may serve as a stem cell source for future cellular therapy for tissue repair and tissue regeneration. In particular, promising results from in- vitro studies using cord blood for engineering blood vessels and heart valves (15) point in this direction (16). Furthermore, in human and animal studies, such cells seem to provide disease-ameliorating effects in conditions such as urinary stress incontinence (17), Alzheimer's disease (18), Huntington's disease (19), amyotrophic lateral sclerosis (20), spinal cord injury (21) diabetes $(22,23)$ myocardial infarction $(24-27)$, to name just a few. The value and power of UCB-SC and the potential they possess for medical treatment and cures is creating a new paradigm for the future. There are already more than 138 clinical trials listed in the U.S under the National Institute of Health forvarious diseases (28). To date, more than 73 diseases were successfully treated using adult SC (29) with more than 20.000 UCB-SC transplants performed for a variety of malignant and non-malignant diseases, mainly due to the fact that they are a rich and readily available source of adult SC (30). The number of children who have received autologous $\mathrm{CB}$ treatment is more than 100 to date (31). The developments in the direction of autologous UCB treatments for diseases, which have a much higher incidence than those requiring allogeneic donors, is supported by research and clinical trials in areas such as neurological disorders (32) and diabetes (33). In contrast to the increasing use of SC such as from UCB to treat various diseases, not a single clinical application is currently available for embryonic stem cells.

\section{Cord blood has advantages over bone marrow}

Advantages of UCB over SCs from the BM or PB of related or unrelated donors include the fact that it is readily available, carries less risk of transmission of blood-borne infectious diseases, and is transplantable across HLA barriers with a diminished risk of GVHD $(34,35)$.

Despite the high value of SC from UCB for clinical applications as well as for research, more than 97 percent are still being discarded. The reasons are manifold, most prominent because their therapeutic potential is still underestimated and undervalued even though they show better results for allogeneic use compared with SC from BM or PB (36-38). Additionally, autologous clinical applications are underrepresented, because most potential recipients are still in their infancy and severe diseases in this phase of life are relatively rare.

Furthermore, most patients who could potentially benefit from an autologous or allogeneic stem cell treatment have no chance to receive their own UCB or UCB from a donor. This is mainly due to the fact that doctors are still reluctant to tell pregnant women of the possibility of storing their child's UCB in a private family bank or to donate it to a public bank.

\section{Conclusion}

It has been estimated that the lifetime probability of undergoing an autologous or allogeneic UCB-SC transplantation is almost $1: 200$ if only $50 \%$ of all haematopoietic diseases, which are treatable with SC, were treated with UCB-SC (not including all other potential non-hematopoietic conditions!) (39). Considering this perspective it seems that all expectant parents should be advised properly by their doctors with complete and up-todate information, thus helping the parents to make a sound decision regarding whether to store the $\mathrm{CB}$ of their baby in a private family bank or to donate it to a public bank. The only wrong decision that actually can be made is throwing away this life saving material.

\section{Conflict of interest}

None declared

\section{References}

1. Karanes C, Confer D, Walker T, Askren A, Keller C. Unrelated donor stem cell transplantation: the role of the National Marrow Donor Program. Oncology (Williston Park) 2003; 17:1036-68, 1043-104, 1164-7.

2. Wagner JE, Rosenthal J, Sweetman R. Successful transplantation of HLA-matched and HLA-mismatched umbilical cord blood from unrelated donors: analysis of engraftment and acute graft-versushost disease. Blood 1996; 88: 795-802.

3. http://www.bmdw.org

4. Frey MA, Guess C, Allison J. Umbilical cord stem cell transplantation. Semin Oncol Nurs 2009; 25: 115-9.

5. Sierra J, Martino R, Sánchez B, Pinana JL, Valcarcel D, Brunet S. Hematopoietic transplantation from adult unrelated donors as treatment for acute myeloid leukemia. Bone Marrow Transplant. 2008; 41: 425-37.

6. Johansen KA, Schneider JF, McCaffree MA. Efforts of the United States' National Marrow Donor Program and Registry to improve utilization and representation of minority donors. Transfus Med. 2008; 18: 250-9

7. Kurtzberg J, Laughlin M, Graham ML, Smith C, Olson JF, Halperin EC, et al. Placental blood as a source of hematopoietic stem cells for transplantation into unrelated recipients. N Engl J Med 1996; 335: 157-66.

8. Rubinstein P, Carrier C, Scaradavou A, Kurtzberg J, Adamson J, Migliaccio AR, et al. Outcomes among 562 recipients of placentalblood transplants from unrelated donors. N Engl J Med. 1998; 339: 1565-77.

9. Rocha V, Wagner JE Jr, Sobocinski KA, Klein JP, Zhang MJ, Horowitz MM, et al. Graft-versus-host disease in children who have received a cord-blood or bone marrow transplant from an HLA-identical sibling. Eurocord and International Bone Marrow Transplant Registry Working Committee on Alternative Donor and Stem Cell Sources. N Engl J Med. 2000; 342: 1846-54.

10. Gluckman E, Broxmeyer HA, Auerbach AD, Friedman HS, Douglas GW, Devergie A, et al. Hematopoietic reconstitution in a patient with Fanconi's anemia by means of umbilical-cord blood from an HLA-identical sibling. N Engl J Med. 1989; 321: 1174-8. 
11. Migliaccio AR, Adamson JW, Stevens CE, Dobrila NL, Carrier CM, Rubinstein P. Cell dose and speed of engraftment in placental/ umbilical cord blood transplantation: graft progenitor cell content is a better predictor than nucleated cell quantity. Blood. 2000; 96: 2717-22.

12. Sauter C, Barker JN. Unrelated donor umbilical cord blood transplantation for the treatment of hematologic malignancies. Curr Opin Hematol. 2008; 15: 568-75.

13. http://www.corduse.com/patients_faq.php

14. Hayani A, Lampeter E, Viswanatha D, Morgan D, Salvi SN. First report of autologous cord blood transplantation in the treatment of a child with leukemia. Pediatrics. 2007; 119: e296-e300.

15. Schmidt D, Asmis LM, Odermatt B, Kelm J, Breymann C, Gössi M, et al. Engineered living blood vessels: functional endothelia generated from human umbilical cord-derived progenitors. Ann Thorac Surg. 2006; 82: 1465-71.

16. Schmidt D, Mol A, Odermatt B, Neuenschwander S, Breymann C, Gössi M, et al. Engineering of biologically active living heart valve leaflets using human umbilical cord-derived progenitors cells. Tissue Eng. 2006; 12: 3223-32.

17. Lee JN, Koh CJ, Lee CS et al. Early phase I/II clinical trial results for human cord blood stem cell injection therapy for stress urinary incontinence. 103rd Annual Meeting of the American Urological Association, Anaheim, CA, USA, 19.-24. Mai 2007.

18. Ende N, Chen R, Ende-Harris D. Human umbilical cord blood cells ameliorate Alzheimer's disease in transgenic mice. J Med. 2002; 32: 241-7.

19. Ende N, Chen R. The effect of a megadose of human umbilical cord blood mononuclear cells on Huntington's disease mice. Am J Clin Pathol. 2000; 114: 4.

20. Chen R, Ende N. The potential for the use of mononuclear cells from human umbilical cord blood in the treatment of amyotrophic lateral sclerosis in SOD1 mice. J Med. 2000; 31: 21-30.

21. Dasari VR, Spomar DG, Gondi CS et al. Axonal remyelination by cord blood stem cells after spinal cord injury. J Neurotrauma 2008; 24: 391-410.

22. Haller MJ, Viener HL, Brusko T et al. Insulin Requirements, HbAlc, and stimulated C-Peptide following autologous Umbilical Cord Blood Transfusion in Children with T1D. 67th Scientific Session of the American Diabetes Association, Chicago, IL, USA; 2007; 22-6.

23. Denner L, Bodenburg Y, Zhao JG, Howe M, Cappo J, Tilton RG, et al. Directed engineering of umbilical cord blood stem cells to produce C-peptide and insulin. Cell Prolif. 2007; 40: 367-80.

24. Henning RJ, Burgos JD, Ondrovic L, Sanberg P, Balis J, Morgan MB. Human umbilical cord blood progenitor cells are attracted to infarcted myocardium and significantly reduce myocardial infarction size. Cell Transplant. 2006; 15: 647-58.
25. Ma N, Stamm C, Kaminski A, Li W, Kleine HD, Müller-Hilke B, et al. Human cord blood cells induce angiogenesis following myocardial infarction in NOD/scid-mice. Cardiovasc Res. 2005; 66: 45-54.

26. Henning RJ, Abu-Ali H, Balis JU, Morgan MB, Willin AE, Sanberg PR. Human umbilical cord blood mononuclear cells for the treatment of acute myocardial infarction. Cell Transplant. 2004; 13: 729-39.

27. Yu G, Borlongan CV, Stahl CE, Yu SJ, Bae E, Yang T, et al. Transplantation of human umbilical cord blood cells for the repair of myocardial infarction. Med Sci Monit. 2008; 14:163-72.

28. http://www.clinicaltrials.gov/ct2/results?term $=\% 22$ umbilical + cord +blood $\% 22+\% 22$ stem + cell $\% 22$

29. www.stemcellresearch.org/facts/checkthescore.pdf; www.stemcellresearch.org/facts/asc-refs.pdf

30. Frey MA, Guess C, Allison J, Kurtzberg J. Umbilical cord stem cell transplantation. Semin Oncol Nurs. 2009; 25: 115-9.

31. http://parentsguidecordblood.org/content/usa/medical/autocbt. shtml)

32. Greschat S, Schira J, Küry P, Rosenbaum C, de Souza Silva MA, Kögler G, et al. Unrestricted somatic stem cells from human umbilical cord blood can be differentiated into neurons with a dopaminergic phenotype. Stem Cells Dev. 2008; 17: 221-32.

33. Haller MJ, Viener HL, Wasserfall C et al. Autologous umbilical cord blood infusion for type 1 diabetes. Exp. Hematol. 2008; 36: 710-5.

34. Rocha V, Wagner JE Jr, Sobocinski KA, Klein JP, Zhang MJ, Horowitz $\mathrm{MM}$, et al. Graft-versus-host disease in children who have received a cord-blood or bone marrow transplant from an HLA-identical sibling. Eurocord and International Bone Marrow Transplant Registry Working Committee on Alternative Donor and Stem Cell Sources. N Engl J Med. 2000; 342: 1846-54.

35. Rocha V, Labopin M, Sanz G, Arcese W, Schwerdtfeger R, Bosi A, et al. Transplants of umbilical-cord blood or bone marrow from unrelated donors in adults with acute leukemia. N Engl J Med 2004; 351: 2276-85

36. Brunstein CG, Barker JN, Weisdorf DJ, Defor TE, Miller JS, Blazar BR, et al. Umbilical cord blood transplantation after nonmyeloablative conditioning: impact on transplantation outcomes in 110 adults with hematologic disease. Blood. 2007; 110: 3064-70.

37. Eapen M, Rubinstein P, Zhang MJ, Stevens C, Kurtzberg J, Scaradavou A et al. Outcomes of transplantation of unrelated donor umbilical cord blood and bone marrow in children with acute leukaemia: a comparison study. Lancet. 2007; 369: 1947-54.

38. Laughlin MJ. Umbilical cord blood for allogeneic transplantation in children and adults. Bone Marrow Transplant. 2001; 27: 1-6.

39. Nietfeld JJ, Pasquini MC, Logan BR, Verter F, Horowitz MM. Lifetime probabilities of hematopoietic stem cell transplantation in the U.S Biol Blood Marrow Transplant. 2008; 14: 316-22. 